\title{
Association with subjective measured physical activity (GPAQ) and quality of life (WHOQoL-BREF) of ageing adults in Hungary, a cross-sectional study
}

Erzsébet Rétsági ${ }^{1}$, Viktória Prémusz ${ }^{2}$, Alexandra Makai ${ }^{1}$, Csaba Melczer $^{1}$, József Betlehem ${ }^{3}$, Kinga Lampek ${ }^{4}$, Pongrác Ács ${ }^{1}$ and Márta Hock ${ }^{1 *}$ (D)

\begin{abstract}
Background: It is well known that physical activity (PA) has health benefits. This study aimed to examine physical activity carried out by the senior (over 50) participants and its relation to their quality of life (QoL).

Methods: Surveillance of PA and QoL was measured by using questionnaires (GPAQ, WHOQOL-BREF) in this study. Descriptive data were presented as means and standard deviations (SD) for continuous variables and as percentages for categorical variables. Multivariate linear regression analysis was conducted. The significance level was set at $p \leq 0.05$.

Results: Overall, 250 participants were recruited, the mean age of the study population ( $n=243$ ) was 70.2 (SD 7.1) years. The results clearly showed that the Hungarian participants aged over 50 years were more likely to do PA if they had university degree and lower age $(p \leq 0.001)$ and used more active transportation $(p=0.035)$ if they had low education. The results of WHOQOL-BREF showed that the Hungarian individuals have better QoL if they have university degree $(p \leq 0.001)$ and lower age $(p \leq 0.001)$. Using multivariate linear regression analysis to examine the effect of PA patterns on QoL adjusted for demographic variables (age, education, BMI, place of living), the result showed significant correlation between WHOQOL-BREF dimensions and GPAQ $(p \leq 0.001)$.
\end{abstract}

Conclusion: Higher amount of PA among aging population can result in better QoL in all dimensions.

Keywords: Physical activity, Aging, Elderly, QoL, GPAQ, WHOQOL-BREF

\section{Background}

Nearly one fifth (19.2\%) of the European Union (EU) population was aged 65 or more in 2017. The ratio of people aged 80 years or more will probably double by 2080 and it will reach $13 \%$ of the whole population [1]. According to data in Hungary, the proportion of people over the age of 60 in 2011 was $23.5 \%$ [2]. In 2015, life

\footnotetext{
* Correspondence: hock.marta@etk.pte.hu

${ }^{1}$ Faculty of Health Sciences, Institute of Physiotherapy and Sport Sciences, University of Pécs, 4 Rét str., Pécs H-7623, Hungary

Full list of author information is available at the end of the article
}

expectancy in Hungary has increased by almost 4 years since 2000, to 75.7 years, but still lags almost 5 years below the EU average. The gap in life expectancy by socioeconomic status is even larger: Hungarian men with the lowest level of education live on average about 9 years less than men with the highest level of education. Nearly $40 \%$ of the overall disease burden in Hungary, as measured by Disability Adjusted Life Years (DALYs) in 2015, can be attributed to unhealthy lifestyles [3]. This is the fourth highest ratio in the EU. Lack of physical activity (PA) is one of the leading behavioral risk factors

(c) The Author(s). 2020 Open Access This article is licensed under a Creative Commons Attribution 4.0 International License, which permits use, sharing, adaptation, distribution and reproduction in any medium or format, as long as you give appropriate credit to the original author(s) and the source, provide a link to the Creative Commons licence, and indicate if changes were made. The images or other third party material in this article are included in the article's Creative Commons licence, unless indicated otherwise in a credit line to the material. If material is not included in the article's Creative Commons licence and your intended use is not permitted by statutory regulation or exceeds the permitted use, you will need to obtain permission directly from the copyright holder. To view a copy of this licence, visit http://creativecommons.org/licenses/by/4.0/ The Creative Commons Public Domain Dedication waiver (http://creativecommons.org/publicdomain/zero/1.0/) applies to the data made available in this article, unless otherwise stated in a credit line to the data. 
contributing to DALYs lost in Hungary [4]. The rate of obese adults has doubled by 2014 compared to the $16 \%$ of 1988. The growth of the rate can be in correlation with ageing [5]. The ageing process is not uniform across the population due to differences in genetics, lifestyle, and overall health [6]. The chronological age of 65 years as a definition of 'elderly' is accepted in general, but the morbidity and mortality rate can begin to increase from 45 years and onwards [7, 8]. Ageing occurs throughout the life course and although there are commonly used definitions of old age, there is no general agreement on the age at which a person becomes old. The changes that constitute and influence ageing are complex [9]. At a biological level, ageing is associated with the gradual accumulation of a wide variety of molecular and cellular damage $[10,11]$. Over time, this damage leads to a gradual decrease in physiological reserves, to an increased risk of many diseases, and to a general decline in the capacity of the individual. These changes may coincide with the retirement period.

Physical inactivity is recognized as a global pandemic $[12,13]$. Around $31 \%$ of the world's population is not meeting the minimum recommendations for PA, with the highest risk group for inactivity being ageing adults [14]. PA has well documented health benefits such as reducing the risks of developing many non-communicable diseases and of premature mortality [12, 14]. There is also evidence that regular and structured PA enhances mobility, enabling older people to maximize quality of life and independence for longer [15]. The benefits of regular PA include weight control, strengthening of muscles and bones, increases in balance and general physical functioning, and improvements in mental health and health-related quality of life (HRQoL) [16-19]. PA appears to be one of the primary strategies to prevent physiological and cognitive illnesses. Regular PA seems to be a protective factor against genetic and molecular aging and can be associated with longevity [19].

To promote health and prevent diseases, it is important to start these in the earlier period of the people's life. This study defines the age groups considered for the study as aged 50 years or older. Promoting PA beneficial for health, particularly among older adults aged 50 years and above, has become a challenge for the public health sector specialists in highly developed societies. Actions taken in this field must be based on a thorough examination of health-oriented behaviors of various social groups, particularly on the role of PA.

Therefore, the aim of our study was to examine physical activity carried out by the ageing residents with particular regard to main socio-demographic parameters, like gender, age and education, and the impact on the different domains of the health-related quality of life.

\section{Methods}

\section{Sample size}

Two hundred fifty participants were recruited (convenience sample) at senior's clubs and retirements associations in Baranya county (Hungary). The data was obtained during face-to-face interviews. We excluded individuals for whom data were missing $(n=7)$. General information on participants was obtained from a paper and pencil questionnaire, including age, gender, educational level and place of living. Educational level was categorized as follows: low (primary schools or less), middle (high school, specialized school and vocational high school), high education (college, university).

Inclusion criteria were age over 50 years; living at home and regularly do not hampered by any illnesses to move and being regularly able to leave the house without physical assistance from another person. Community-dwelling ageing people were excluded, if they were housebound (couldn't go outside without physical assistance from another person in the past month) or having a cognitive impairment (a diagnosis of dementia or a memory impairment). People having insufficient Hungarian language skills, progressive neurological diseases or medical conditions precluding exercise were also excluded.

\section{Outcome measures \\ Anthropometric properties}

The body mass was measured in kilograms $(\mathrm{kg})$ and the height in meters $(\mathrm{m})$, using a $150 \mathrm{~kg}$ capacity digital platform scale (OMRON B511), with a precision of $0.5 \mathrm{~kg}$, and a rigid tape measure of $2 \mathrm{~m}$ and $50 \mathrm{~cm}$, respectively. From body mass and height measurements, the Body Mass Index (BMI $-\mathrm{kg} / \mathrm{m}^{2}$ ) was calculated (low BMI, if $\mathrm{BMI} \leq 18.5 \mathrm{~kg} / \mathrm{m}^{2}$; normal, if BMI was between 18.5 and $24.9 \mathrm{~kg} / \mathrm{m}^{2}$; overweight, if BMI was 25 to $29.9 \mathrm{~kg} / \mathrm{m}^{2}$; obesity, if BMI was 30 to $34.9 \mathrm{~kg} / \mathrm{m}^{2}$; and obesity grade II was defined as BMI $35 \mathrm{~kg} / \mathrm{m}^{2}$ ) [20].

A flexible and inextensible plastic tape, with a precision of $0.1 \mathrm{~cm}$, was used to measure body circumference in centimeters $(\mathrm{cm})$, according to conventional techniques. Waist circumference (WC) was measured at the midpoint between the lower margin of the last palpable rib and the top of the iliac crest based on the WHO STEP wise approach to surveillance (STEPS) protocol, while the hip circumference $(\mathrm{HC})$ was measured around the widest portion of the buttocks in a standing position wearing light clothing and looking straight ahead with arms at the sides and feet adherent to each other. The WHO STEPS protocol suggests that the waist circumference should be measured at the end of a normal expiration, when the lungs are at their functional residual capacity [21]. The measuring tape was kept horizontal during the measurement of the $\mathrm{HC}$ and WC. WC and 
$\mathrm{HC}$ were recorded to the nearest $\mathrm{cm}$ and waist-hip ratio (WHR) was defined as a ratio of WC to $\mathrm{HC}$. Abnormal WC and WHR were defined with clinically acceptable standard cut-offs. High WC was defined as cut-offs of $80 \mathrm{~cm}$ for women and $94 \mathrm{~cm}$ for men; high WHR was defined on the basis of World Health Organization criteria as 0.85 for women and 0.90 for men [22].

\section{Global physical activity questionnaire}

Surveillance of PA in populations is most often undertaken using questionnaires, as these are relatively inexpensive and easy to administer compared to objective measurement techniques. In this study, PA levels were determined by Global Physical Activity Questionnaire (GPAQ).

GPAQ is a suitable and acceptable instrument for monitoring PA in population health surveillance systems [23-25].

The Global Physical Activity Questionnaire was developed by WHO for PA surveillance in countries. This questionnaire was stated as an adequate measurement tool of PA in the elderly [24, 26, 27]. The validated Hungarian version, GPAQ-H was used in the study [28]. It collects information on PA participation in three settings (or domains) as well as on sedentary behavior, comprising 16 questions (P1-P16). The domains are: Activity at work; travel to and from places and recreational activities. For analysis purposes these domains can be further broken down into six different "sub-domains". These "sub-domains" are: vigorous work (codes P1-P3); moderate work (codes P4-P6); travel (codes P7-P9); vigorous recreation (codes $\mathrm{P} 10-\mathrm{P} 12)$; moderate recreation (codes P13-P15); sitting (code P16).

Following the Global Physical Activity Questionnaire (GPAQ) Analysis Guide Vigorous-intensity activities were described as activities that cause large increases in breathing or heart rate like carrying or lifting heavy loads, digging, construction work, running or football. Moderate activities were considered as any activities that cause a small increase in breathing or heart rate such as brisk walking for at least $10 \mathrm{~min}$ continuously, i.e. carrying light loads, cycling, swimming or volleyball [29]. Moderate to Vigorous Physical Activity (MVPA) was calculated as the sum of the respective minutes of moderate and vigorous activities of work and leisure time domains. By active transportation GPAQ only describes the duration of the activity without indicating the intensity, as" the usual way of travel to and from places, for example to work, for shopping, to market, to place of worship". Therefore, the analysis of the test results was completed with a "total" category, which sums up all the minutes spent with PA.

\section{WHO's HRQoL scale (WHOQoL-BREF)}

We used the brief version of the WHO's Quality of Life (QoL) questionnaire (WHOQoL-BREF) from the WHOQoL-100 in this study. The WHOQoL-BREF questionnaire contains two items on overall QoL and general health, and 24 items on different aspects of quality of life that are divided into four domains: physical health with 7 items, psychological health with 6 items, social relationships with 3 items and environmental with 8 items. It has five points Likert-type of scale and higher scores indicated better QoL and the maximum point is 100 . It is a valid and reliable measure of the QoL of elderly people [30-32].

\section{Ethical considerations}

All participants were informed of the study's goals and details, and written informed consent was obtained from participants. The study was conducted in accordance with the World Medical Association's Helsinki Declaration for Human Studies [33]. This study was approved by the Institutional Review Board of the Faculty of Medicine, University of Pécs, in 2017 (No. 6955).

\section{Data analysis}

Descriptive data were presented as means and standard deviations (SD) for continuous variables and as percentages for categorical variables. To express differences between the socio-demographic, QoL and PA parameters, the independent Mann-Whitney $U$ and Kruskal-Wallis tests was used for the continuous variables and the chisquare test for the categorical variables.

To examine the effect of PA patterns adjusting for demographic variables (age, education, BMI, place of living) we used multivariate linear regression analysis. The significance level was set at $p<0.05$. For statistical analysis SPSS 24.0 software were used.

\section{Results}

For the present study, a complete data of 243 participants were used in the analyses. Overall, 250 participants were recruited in the current study. The mean age of the study population was 70.20 (SD 7.10) years. Among these 243 participants $38.68 \%$ were man and $61.32 \%$ were woman. The half of participants had secondary education (49.79\%). The majority of the elderly were obese and had higher BMI $\left(26.95 \mathrm{~kg} / \mathrm{m}^{2}\right)$. Results of the anthropometric characteristics of the genders showed that men have significantly higher BMI $(p=0.001)$ than women. Value of waist circumference was also high in both genders. Results of WHR was 0.91 (men) versus 0.88 (women), which was higher than normal. There were no statistically significant differences in educational attainment, age, and place of living between the genders. The comparative results of the sociodemographic and 
the anthropometric profile's characteristics for the study participants are presented in Table 1.

One hundred and seventy-two participants (70.78\%) were classified as physically inactive. $80.25 \%$ of the examined population self-reported 'average', 'good' and 'very good' health status.

The results clearly showed in general that the Hungarian participants aged over 50 years are more likely to do PA if they have lower age and college or university degree $(p \leq 0.001)$ except active transport which was significantly more preferred by individuals with lower educational level $(p=0.035)$. Daily sitting time was similar, gender differences could not be described (Table 2).

The results of WHOQoL-BREF showed that the participants had better QoL if they had higher degree (physical health, $p \leq 0.001$; psychological, $p \leq 0.001$; social relationships, $p \leq 0.001$; environment, $p \leq 0.001$ ) and lower age (physical health, $p \leq 0.001$; psychological, $p \leq 0.001$; social relationship, $p=0.002$ ). (Table 3 ).

There was no significant correlation between workrelated PA or active transport and QoL. Although, positive significant association was found between recreational activity and all domains of QoL $(\leq 0.001)$. Sedentary behavior showed negative relationship with psychological health $(R=-0.204, p \leq 0.001)$. If the results were analyzed regarding the intensity and the total amount of PA, positive association could be described with QoL, except the environment domain, as shown in Table 4.

In our study, multivariate linear regression analysis was used to examine the effect of PA on QoL adjusted for demographic and anthropometric variables (age, education, BMI, place of living). WHOQoL-BREF measures QoL in four domains, therefore, the analysis was conducted along these four domains.

Table 1 Descriptive characteristics of the participants by genders

\begin{tabular}{|c|c|c|c|c|c|c|c|}
\hline & \multicolumn{2}{|l|}{ Total } & \multicolumn{2}{|l|}{ Female } & \multicolumn{2}{|l|}{ Male } & \multirow[b]{2}{*}{$\mathrm{p}$} \\
\hline & Mean or Frequency & SD or $\mathrm{N}$ & Mean or Frequency & SD or N & Mean or Frequency & SD or $N$ & \\
\hline \multicolumn{8}{|l|}{ Gender } \\
\hline Female & 61.32 & 149 & & & & & \\
\hline Male & 38.68 & 94 & & & & & \\
\hline \multicolumn{8}{|l|}{ Age groups } \\
\hline $50-59$ & 20.16 & 49 & 18.79 & 28 & 22.34 & 21 & 0.615 \\
\hline $60-64$ & 18.52 & 45 & 17.45 & 26 & 20.21 & 19 & \\
\hline $65-$ & 61.32 & 149 & 63.76 & 95 & 57.45 & 54 & \\
\hline \multicolumn{8}{|l|}{ Education } \\
\hline Low & 15.64 & 38 & 16.11 & 24 & 14.89 & 14 & 0.966 \\
\hline Middle & 49.79 & 121 & 49.66 & 74 & 50.00 & 47 & \\
\hline High & 34.57 & 84 & 34.23 & 51 & 35.11 & 33 & \\
\hline \multicolumn{8}{|l|}{ Place of living } \\
\hline Urban & 71.60 & 174 & 72.48 & 108 & 70.21 & 66 & 0.702 \\
\hline Rural & 28.40 & 69 & 27.52 & 41 & 29.79 & 28 & \\
\hline \multicolumn{8}{|l|}{ Anthropometric properties } \\
\hline Height $(\mathrm{cm})$ & 168.17 & 8.78 & 164.14 & 7.31 & 174.50 & 7.01 & $\leq 0.001$ \\
\hline Weight (kg) & 76.16 & 14.50 & 70.48 & 11.45 & 85.33 & 14.26 & $\leq 0.001$ \\
\hline Waist circumference $(\mathrm{cm})$ & 95.93 & 16.08 & 92.00 & 17.29 & 102.73 & 11.04 & 0.003 \\
\hline Hip circumference $(\mathrm{cm})$ & 106.91 & 23.78 & 107.32 & 28.19 & 106.23 & 13.87 & 0.091 \\
\hline Waist to hip ratio & 0.98 & 0.11 & 0.88 & 0.18 & 0.91 & 0.16 & $\leq 0.001$ \\
\hline BMI & 26.95 & 4.50 & 26.26 & 4.75 & 28.04 & 3.85 & $\leq 0.001$ \\
\hline \multicolumn{8}{|l|}{ Health status } \\
\hline Average, good, very good (\%) & 80.25 & 202 & 79.87 & 119 & 80.85 & 76 & 0.475 \\
\hline \multicolumn{8}{|l|}{ Sport } \\
\hline Does not do any sports regularly & 70.78 & 172 & 67.79 & 101 & 75.53 & 71 & 0.196 \\
\hline Does sport regularly & 29.22 & 71 & 32.21 & 48 & 24.47 & 23 & \\
\hline
\end{tabular}

BMI Body Mass Index; N number; SD standard deviation 
Table 2 Results of the GPAQ domains by the different demographic variables in ageing adults in Hungary

\begin{tabular}{|c|c|c|c|c|c|c|c|c|c|c|}
\hline & $\min / \mathrm{we}$ & & $\begin{array}{l}\text { Work time } \\
\text { activities }\end{array}$ & $\begin{array}{l}\text { Active } \\
\text { transport }\end{array}$ & $\begin{array}{l}\text { Leisure time } \\
\text { activities }\end{array}$ & $\begin{array}{l}\text { Daily sitting } \\
\text { time }\end{array}$ & $\begin{array}{l}\text { Moderate } \\
\text { activities }\end{array}$ & $\begin{array}{l}\text { Vigorous } \\
\text { activities }\end{array}$ & MVPA & $\begin{array}{l}\text { Total } \\
\text { PA }\end{array}$ \\
\hline \multirow[t]{5}{*}{ Gender } & Male & Mean & 346.28 & 169.87 & 63.14 & 348.60 & 253.99 & 155.43 & 409.41 & 579.29 \\
\hline & & Std. Deviation & 795.93 & 353.85 & 170.82 & 227.00 & 477.10 & 492.07 & 821.24 & 913.38 \\
\hline & Female & Mean & 591.51 & 156.24 & 72.05 & 365.77 & 587.08 & 76.48 & 663.56 & 819.80 \\
\hline & & Std. Deviation & 4721.54 & 307.38 & 163.59 & 230.28 & 4737.83 & 223.66 & 4770.45 & 4772.54 \\
\hline & $p$ value & & 0.876 & 0.982 & 0.564 & 0.456 & 0.966 & 0.990 & 0.817 & 0.957 \\
\hline \multirow[t]{7}{*}{ Education } & Low & Mean & 243.55 & 309.08 & 25.26 & 378.37 & 217.63 & 51.18 & 268.82 & 577.89 \\
\hline & & Std. Deviation & 385.55 & 667.28 & 96.27 & 267.81 & 344.87 & 168.87 & 436.38 & 763.94 \\
\hline & Middle & Mean & 771.12 & 150.17 & 63.97 & 369.09 & 711.28 & 123.80 & 835.08 & 985.25 \\
\hline & & Std. Deviation & 5252.92 & 210.14 & 190.71 & 222.85 & 5261.70 & 353.71 & 5309.04 & 5307.64 \\
\hline & High & Mean & 215.77 & 111.11 & 94.88 & 336.07 & 202.56 & 108.10 & 310.65 & 421.76 \\
\hline & & Std. Deviation & 569.18 & 183.93 & 148.87 & 218.81 & 303.36 & 411.57 & 576.30 & 631.25 \\
\hline & $p$ value & & 0.322 & 0.035 & $<0.001$ & 0.477 & 0.178 & 0.294 & 0.183 & $<0.001$ \\
\hline \multirow[t]{7}{*}{ Age group } & $50-59$ & Mean & 1597.35 & 145.82 & 161.43 & 324.04 & 1488.47 & 270.31 & 1758.78 & 1904.59 \\
\hline & & Std. Deviation & 8215.57 & 185.05 & 199.60 & 202.04 & 8237.32 & 616.02 & 8286.44 & 8275.17 \\
\hline & $60-64$ & Mean & 480.44 & 111.67 & 50.33 & 327.56 & 386.00 & 144.78 & 530.78 & 642.44 \\
\hline & & Std. Deviation & 779.39 & 173.80 & 133.64 & 234.85 & 558.52 & 364.04 & 789.13 & 841.84 \\
\hline & $65-$ & Mean & 139.56 & 181.73 & 43.59 & 380.20 & 141.24 & 41.91 & 183.15 & 364.89 \\
\hline & & Std. Deviation & 337.45 & 389.74 & 152.69 & 233.95 & 282.63 & 169.09 & 363.74 & 557.34 \\
\hline & $p$ value & & $<0.001$ & 0.363 & $<0.001$ & 0.131 & $<0.001$ & $<0.001$ & $<0.001$ & 0.515 \\
\hline \multirow[t]{2}{*}{ Total } & & Mean & 496.65 & 161.51 & 68.60 & 359.13 & 458.23 & 107.02 & 565.25 & 726.76 \\
\hline & & Std. Deviation & 3727.13 & 325.49 & 166.13 & 228.70 & 3720.47 & 353.73 & 3767.25 & 3776.79 \\
\hline
\end{tabular}

min/week minutes per week; MVPA moderate to vigorous physical activity; PA physical ac tivity; Std standard

Negative significant correlation was found between age, BMI and place of living (rural residence) and QoL domains and positive significant relationship between QoL and education.

Time spent with leisure time activity showed significant positive relationship with physical health, psychological domain and social relationships. Active transport (time spent with walking or cycling) correlated only with psychological domain (Table 5).

\section{Discussion}

One of the most significant challenges may become the lack of PA among the ever-expanding aging population. The lifestyle, more specifically the PA regimen of an individual, changes throughout the lifespan. A significant change in life experienced by individuals older than 50 years could be their transition from employment to retirement, which may influence the health and PA areas. The transition to retirement might lead to a decreased volume of daily PA and at the same time, particularly as a result of an increase in leisure time, the proportion of PA might increase [34, 35]. The health of retirement-age adults has increasing public health importance in Hungary as well, given the demographic trends. By mitigating individuals' time constraints, retirement provides new opportunities for adopting more physically active lifestyles and increasing the frequency and duration of leisure-time physical exercise [36]. The results of present research can provide further details to PA recommendations with the analysis of PA patterns of aging people in Hungary.

At present, Hungarians are among the most obese nations in Europe, and are in fourth place on a global scale, which may be one of the explanations for poor morbidity and mortality statistics in Hungary [4]. The central obesity is strongly associated with cardiovascular morbidity and mortality [37]. Cardiovascular disease is responsible for more than half of the deaths for people in Hungary. Age-standardized death rates of cardiovascular diseases were more than the double of the EU average in 2014, mainly due to the greater prevalence of smoking and obesity as well [4]. In spite of that, it is well known that regular PA is the most evidence-based strategy for reducing cardiovascular disease risk with aging in both sexes, only total of $29.22 \%$ Hungarian participants meet the PA suggestion of ACSM [38]. In a recent analysis of large longitudinal studies by Myers et al. it was found that people who engaged in $150 \mathrm{~min}$ moderate intensity (or equivalent) PA per week, had a 31\% reduction in mortality compared to those who were less active [39]. 
Table 3 Results of the WHOQOL-BREF domains by the different demographic variables in ageing adults in Hungary

\begin{tabular}{|c|c|c|c|c|c|}
\hline & & Physical health & Psychological domain & Social relationships & Environment domain \\
\hline \multicolumn{6}{|l|}{ Gender } \\
\hline \multirow[t]{2}{*}{ Male } & Mean & 58.28 & 63.07 & 61.63 & 61.10 \\
\hline & SD & 13.63 & 15.40 & 16.92 & 14.72 \\
\hline \multirow[t]{2}{*}{ Female } & Mean & 58.54 & 61.84 & 63.59 & 62.55 \\
\hline & SD & 14.34 & 15.79 & 16.79 & 15.34 \\
\hline$p$ value & & 0.827 & 0.516 & 0.196 & 0.370 \\
\hline \multicolumn{6}{|l|}{ Education } \\
\hline \multirow[t]{2}{*}{ Low } & Mean & 54.42 & 53.89 & 56.55 & 56.18 \\
\hline & SD & 12.19 & 11.73 & 13.83 & 14.92 \\
\hline \multirow[t]{2}{*}{ Middle } & Mean & 56.21 & 59.45 & 59.77 & 58.90 \\
\hline & SD & 13.94 & 14.93 & 16.32 & 14.47 \\
\hline \multirow[t]{2}{*}{ High } & Mean & 63.45 & 70.26 & 70.08 & 69.06 \\
\hline & SD & 13.70 & 14.81 & 16.46 & 13.48 \\
\hline$p$ value & & $<0.001$ & $<0.001$ & $<0.001$ & $<0.001$ \\
\hline \multicolumn{6}{|c|}{ Age group } \\
\hline \multirow[t]{2}{*}{$50-59$} & Mean & 66.24 & 69.33 & 69.45 & 64.24 \\
\hline & SD & 11.69 & 13.99 & 17.42 & 15.71 \\
\hline \multirow[t]{2}{*}{$60-64$} & Mean & 64.47 & 65.47 & 65.96 & 63.09 \\
\hline & SD & 12.25 & 13.93 & 13.05 & 15.84 \\
\hline \multirow[t]{2}{*}{$65-$} & Mean & 54.05 & 59.06 & 59.71 & 60.91 \\
\hline & $\mathrm{SD}$ & 13.52 & 15.74 & 16.94 & 14.64 \\
\hline$p$ value & & $<0.001$ & $<0.001$ & 0.002 & 0.354 \\
\hline \multicolumn{6}{|l|}{ Total } \\
\hline \multirow[t]{2}{*}{ Total } & Mean & 58.44 & 62.32 & 62.83 & 61.99 \\
\hline & SD & 14.04 & 15.62 & 16.83 & 15.09 \\
\hline
\end{tabular}

$S D$ standard deviation

On the other hand, one major determinant for overweight/obesity is physical inactivity. Asp and colleagues found strong independent associations between both PA and obesity, and between physical mobility and obesity in the elderly [40].

As an earlier study showed, the environment might influence the PA of individuals. Smaller residential areas indicate a higher proportion of weekly PA [41]. The inhabitants of smaller towns and villages are more likely to achieve PA recommendations [42]. Seniors living in residential areas with $\leq 100,000$ inhabitants are more likely to achieve the walking recommendation in the context of overall walking as well as active transport [43]. In contrast, our findings suggest, that urban living has a positive impact on quality of life, the urban residents have better QoL, than rural residents. In our present study, the amount of urban (71.6\%) individuals were more than rural, but this ratio nearly represents the Hungarian (69.5\%) distribution [2]. Earlier, the influences of cities' environmental and built factors were widely demonstrated in the quality of life of aging population [44, 45].

Essential amount of PA can be reported by the aging population in the context of active transport. Based on previous results, PA performed during leisure time and total PA (transportation, work, housework and leisure) can predict the absence of frailty in the elderly [42]. Promoting active transport offers the potential to increase PA levels especially among older adults, since few participate in sport and exercise $[18,46]$. Based on our results, the active transportation proved to be one of the good possibilities in elevating the PA level among loweducated older individuals. This information may be relevant for planning services for older people in Hungary.

Education factor is one of the basic determinants of health conscious behavior [47] and of PA [8]. The impacts of education on health are known to derive from 
Table 4 Correlation between physical activity (measured with GPAQ) and quality of life (measured with WHOQoL-BREF) domains in ageing adults in Hungary

\begin{tabular}{|c|c|c|c|c|c|c|}
\hline & & & Physical health & Psychological domain & Social relationships & Environment domain \\
\hline \multirow[t]{16}{*}{ GPAQ } & \multirow[t]{2}{*}{ Work } & $\mathrm{R}$ & 0.059 & 0.049 & 0.066 & 0.000 \\
\hline & & $\mathrm{p}$ & 0.363 & 0.445 & 0.307 & 0.999 \\
\hline & \multirow[t]{2}{*}{ Travel to and from places } & $\mathrm{R}$ & 0.053 & 0.080 & 0.000 & 0.007 \\
\hline & & $\mathrm{p}$ & 0.415 & 0.216 & 0.998 & 0.916 \\
\hline & \multirow[t]{2}{*}{ Recreational activities } & $\mathrm{R}$ & $0.343^{* *}$ & $0.289^{* *}$ & $0.308^{* *}$ & $0.239^{* *}$ \\
\hline & & $\mathrm{p}$ & $\leq 0.001$ & $\leq 0.001$ & $\leq 0.001$ & $\leq 0.001$ \\
\hline & \multirow[t]{2}{*}{ Sedentary behaviour } & $\mathrm{R}$ & -0.118 & $-0.204^{* *}$ & -0.120 & -0.061 \\
\hline & & $\mathrm{p}$ & 0.067 & $\leq 0.001$ & 0.062 & 0.346 \\
\hline & \multirow[t]{2}{*}{ Moderate PA } & $\mathrm{R}$ & $0.173^{* *}$ & $0.180^{* *}$ & $0.181^{* *}$ & $0.136^{*}$ \\
\hline & & $p$ & 0.007 & 0.005 & 0.005 & 0.034 \\
\hline & \multirow[t]{2}{*}{ Vigorous PA } & $\mathrm{R}$ & $0.250^{* *}$ & $0.204^{* *}$ & $0.186^{* *}$ & 0.098 \\
\hline & & $\mathrm{p}$ & $\leq 0.001$ & $\leq 0.001$ & 0.004 & 0.127 \\
\hline & \multirow[t]{2}{*}{ MVPA } & $\mathrm{R}$ & $0.205^{* *}$ & $0.202^{* *}$ & $0.206^{* *}$ & $0.149^{*}$ \\
\hline & & $\mathrm{p}$ & $\leq 0.001$ & 0.002 & 0.001 & 0.020 \\
\hline & \multirow[t]{2}{*}{ Total PA } & R & $0.215^{* *}$ & $0.208^{* *}$ & $0.138^{*}$ & 0.115 \\
\hline & & $\mathrm{p}$ & 0.001 & 0.001 & 0.032 & 0.073 \\
\hline
\end{tabular}

**Correlation is significant at the 0.01 level; ${ }^{*}$ Correlation is significant at the 0.05 level (2-tailed) $R$ correlation coefficient; $p$ significance (2-tailed)

MVPA moderate to vigorous physical activity; PA physical activity

knowledge that allow better educated persons to gain access and information on physical activity-promoting resources [48]. Education has a major impact on the quality of life of individuals as revealed by our current findings. According to an earlier study, the amount of occupational PA increases with lower education and higher education may lead to increased leisure PA [49]. Which are in line with the results of our GPAQ analysis, the Hungarian participants aged 50 years and older are more likely to do leisure time activity if they have university/college degree.
This finding is consistent with other studies, in which higher education was positively associated with meeting health recommendations and higher education leads to increased leisure PA as well [36]. In our study, results showed, that low-educated individuals participated in active transportation to a greater extent, they walk and use bicycle more frequently. The one third of the Hungarian population (31.7\%) have primary-level education [2]. These findings on active transportation could help in the customization of PA programs for the ageing people.

Table 5 Relationship between the WHOQOL-BREF dimensions and demographic variables

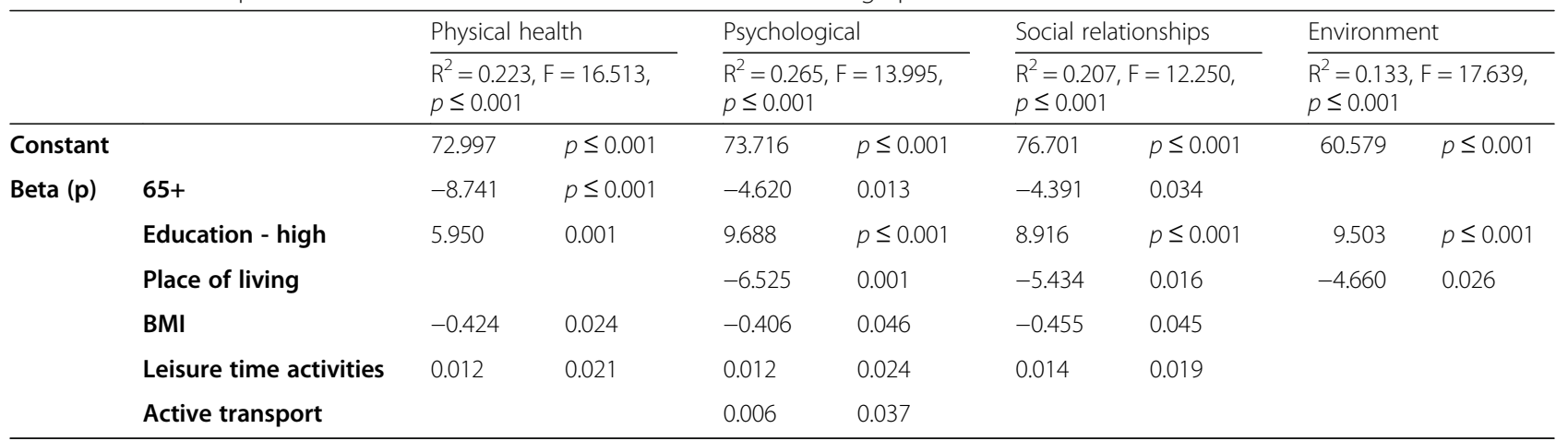


In the present research, people between 50 and 59 years, did more work-related activities, leisure physical activity, vigorous, moderate and total MVPA as well, than older participants. Data from the Baltimore Longitudinal Study on Aging showed remarkable differences in activity levels between the subgroups under 60 and over 75 years [50]. In another examined sample, PA levels decreased also significantly in 10-year-group categories as the age advanced [51].

More than three quarters of the examined population was satisfied with their own health. A previous research showed similar findings, Irish people aged 50+ also reported high life satisfaction [52]. The patients' feeling of their own good health is an important aspect of positive ageing. It is also a good predictor of other important ageing outcomes, morbidity and mortality.

The QoL of respondents was measured by WHOQoL-BREF questionnaire. In the present research, participants, who had higher degree of education (all dimension of WHOQoL-BREF) and lower age had better QoL, except the environment domain.

Being overweight interfered with QoL equally in both sexes, people with lower BMI had better QoL than individuals with higher BMI [53]. Higher age may be associated with higher BMI [54]. A negative correlation was confirmed in the adult population between BMI and vigorous PA as well. In persons aged $\geq 50$ years with normal BMI the prevalence of a sedentary lifestyle is $9.5 \%$, while in obese individuals it is higher, $10.7 \%[54,55]$. In the aging population, individuals with normal BMI achieve significantly more steps/day than individuals with overweight and obesity. Weekend days (especially Sunday) were the days with the lowest number of steps in men and women aged $\geq 50$ years with overweight and obesity [56]. Present results indicated an association between increased BMI and decreased QoL in almost all domains (except environmental) of the WHOQoL-BREF.

Our present results showed strong connection between WHOQoL-BREF domains and different demographic variables. We used multivariate linear regression analysis to examine the effect of PA adjusted for demographic and anthropometric (age, education, BMI, place of living) variables. Our results are in line with former findings, i.e. men and women aged $\geq 65$ years report less overall PA compared with men and women aged 50 to 64 years [55]. Professionals should in particular pay attention to physical inactivity (among others) among older people (70 years or older), because it's relation with quality of life seems to be the strongest [57].

Quality of life and PA data was analyzed by WHOQoL-BREF and GPAQ. Our study showed that significant correlations can be found between the domains of QoL and the PA level. According to the results of this study, recreational activity, vigorous PA, moderate PA and MVPA also improves the respondents' QoL of physical health domain. According to Puciato et al., the PA level determined the quality of life in older working age populations. Quality of life in the physical dimension was assessed as the highest in the physically most active participants [58].

The present study, as well as some former research, revealed positive relationships between PA and the psychological dimension of quality of life [59]. Some earlier findings suggest that the psychological quality of life was positively affected by moderate- and high-intensity exercises, which was also verified by our present findings [60]. We revealed, that psychological dimension shows inverse connection with sedentary behavior. Sedentary behavior, or time spent non-exercising, reclining and doing seated activities, is emerging as an important public health issue, particularly amongst older people who are the most sedentary group within the population. Several national guidelines recommend a reduction in sedentary behavior for the older adult population [38], although there is little knowledge about factors, that determine sedentary behavior within this population group and how to develop interventions that lead them into changing their behavior.

The present study also confirmed the positive connection between the social relationships' dimension of quality of life and physical activity, with particular regard to recreational activity, vigorous $\mathrm{PA}$, moderate PA and MVPA. This is highly essential since the first symptoms of body aging may appear in people over 50 years old. These symptoms can have a negative impact on the individual's functioning in society and interpersonal relations. Thus, in the social relationships area, PA can play preventive roles. Some authors point out that the levels of PA are higher among individuals with enough leisure time (or with sufficient material resources) [61, 62].

The 4th dimension of the WHOQoL-BREF (environment) showed positive correlation with results of recreational activity and MVPA of GPAQ. Among participants who were more active the environment dimension was significantly better.

\section{Study limitations and strengths}

A number of limitations of the study should be mentioned. First, the present study used a relatively small convenience sample of older adults. Second, this study applied a questionnaire-based assessment of PA, which has some limitations. Third, this study did not include complete information from medical records or health examinations about participants.

Consequently, the findings cannot be generalized to older adults with more serious health conditions. 
Nevertheless, we believe that these limitations do not prevent drawing conclusions from the study.

The strength of the present study is the comprehensive assessment of quality of life in older people. In addition, a large age range of elderly (from 50 years) was studied. Earlier studies on elder populations in bigger countries of Europe and in Hungary clarified, that the social and economic changes related to the transformation from centrally planned to free market economy and gradual convergence with the most highly developed countries can raise question about changes of practice of PA in old age [63, 64]. The important question is how to motivate people to change habits, who are the least motivated because of social and/or economic reasons.

\section{Conclusion}

Although, the sociodemographic and anthropometric characteristics (age, education, place of living and BMI) have an undeniable effect on the quality of life of elderly, PA and particularly leisure time recreational activity plays an important role as well. Elderly, who do more PA have better quality of life in all dimension of WHOQOL-BREF.

\begin{abstract}
Abbreviations
ACSM: American College of Sports Medicine; BMI: Body Mass Index; DALYs: Disability Adjusted Life Years; EU: European Union; GPAQ: Global Physical Activity Questionnaire; HC: Hip circumference; HRQoL: HealthRelated Quality of Life; min/week: Minutes per week; MVPA: Moderate to vigorous physical activity; N: Number; PA: Physical activity; Std: Standard; SD: Standard deviation; QoL: Quality of Life; WC: Waist circumference; WHR: Waist-hip ratio; WHO: World Health Organization
\end{abstract}

\section{Acknowledgements}

Not applicable.

\section{About this supplement}

This article has been published as part of BMC Public Health Volume 20 Supplement 1, 2020: Level and Determinants of Physical Activity in the V4 Countries - Part 1. The full contents of the supplement are available online at URL.https://bmcpublichealth.biomedcentral.com/articles/supplements/ volume-20-supplement-1.

\section{Authors' contributions}

All authors contributed to the design of the study (ER, AM, KL, VP, CSM, PÁ, $J B, M H)$. VP, CSM collected the data. AM, PÁ and KL analyzed the data. The next authors interpreted the data: $E R, J B, M H . M H$ drafted, $M H$ and VP final edited the manuscript. All authors contributed to, read and approved the final manuscript (ER, $A M, K L, V P, C S M, P A, J B, M H)$.

\section{Funding}

The publication costs were funded by the GINOP 2.3.2-15-2016-00047 grant. The authors declare that the study design; collection, management, analysis, and interpretation of data; writing of the manuscript are independent of GINOP.

\section{Availability of data and materials}

The datasets used and/or analyzed during the current study are available from the corresponding author on reasonable request.

\section{Ethics approval and consent to participate}

The ethical approval was granted for the study by Ethics Committee of University of Pécs. (6955/2017). The participants were informed about the research aim and methods before signing the informed consent form. The investigation conforms to the principles outlined in the Declaration of Helsinki.

\section{Consent for publication}

Not applicable.

\section{Competing interests}

The authors declare that they have no competing interests.

\section{Author details}

${ }^{1}$ Faculty of Health Sciences, Institute of Physiotherapy and Sport Sciences, University of Pécs, 4 Rét str., Pécs H-7623, Hungary. ${ }^{2}$ Faculty of Health Sciences, Doctoral School of Health Sciences, University of Pécs, 4 Vörösmarty str., Pécs H-7621, Hungary. ${ }^{3}$ Faculty of Health Sciences, Institute of Emergency Care and Health Pedagogy, University of Pécs Pécs, 4 Vörösmarty str., Pécs H-7621, Hungary. ${ }^{4}$ Department of Public Health and Health Promotion, Faculty of Health Sciences, Institute of Health Insurance, University of Pécs, 5-7 Mária str., Pécs H-7621, Hungary.

Received: 29 April 2020 Accepted: 1 May 2020

Published: 17 August 2020

\section{References}

1. Population structure and ageing, Retrieved 30/06, 2019, from [https://ec. europa.eu/eurostat/statistics-explained/index.php/Population_structure_ and_ageing].

2. Growing Population - Characteristics of the Elderly [A népesség gyarapodó rétege - Az időskorúak jellemzői], Retrieved 30/06, 2019, from [https://www. ksh.hu/docs/hun/xftp/idoszaki/pdf/nepesseg_gyarapodo.pdf].

3. Global all-cause deaths and DALYs for 2017 with trends since 1990, Retrieved 05/07, 2019, from [http://ghdx.healthdata.org/gbd-results-tool].

4. State of health in the eu: Country health profile 2017 - Hungary, Retrieved 05/06, 2019, from [http://www.euro.who.int/_data/assets/pdf_file/0006/355 983/Health-Profile-Hungary-Eng.pdf?ua=1 ].

5. Obesity Update 2017, Retrieved 05/06, 2019, from [http://www.oecd.org/ health/health-systems/Obesity-Update-2017.pdf].

6. Levine ME. Modeling the rate of senescence: can estimated biological age predict mortality more accurately than chronological age? J Gerontol A Biol Sci Med Sci. 2013;68(6):667-74.

7. Stern TA, Fava M, Wilens TE, Rosenbaum JF. Massachusetts general hospital comprehensive clinical psychiatry: Elsevier health sciences; 2015.

8. WHO: World report on ageing and health: World Health Organization; 2015.

9. Boros K, Freemont T. Physiology of ageing of the musculoskeletal system. Best Practice \& Research in Clinical Rheumatology. 2017:31 (2):203-17.

10. Steves CJ, Spector TD, Jackson SHD. Ageing, genes, environment and epigenetics: what twin studies tell us now, and in the future. Age Ageing. 2012;41(5):581-6.

11. Xia X, Chen W, McDermott J, JDJ H. Molecular and phenotypic biomarkers of aging. F1000Res. 2017;6:860.

12. Lee IM, Shiroma EJ, Lobelo F, Puska P, Blair SN, Katzmarzyk PT. Effect of physical inactivity on major non-communicable diseases worldwide: an analysis of burden of disease and life expectancy. Lancet (London, England). 2012:380(9838):219-29.

13. Kohl HW, Craig CL, Lambert EV, Inoue S, Alkandari JR, Leetongin G, Kahlmeier S. Lancet Phys Activity Series W: The pandemic of physical inactivity: global action for public health. Lancet (London, England). 2012; 380(9838):294-305.

14. Heath GW, Parra DC, Sarmiento OL, Andersen LB, Owen N, Goenka S, Montes F, Brownson RC. Lancet Phys Activity Series W: Evidence-based intervention in physical activity: lessons from around the world. Lancet (London, England). 2012;380(9838):272-81.

15. Pahor M, Guralnik JM, Ambrosius WT, Blair S, Bonds DE, Church TS, Espeland MA, Fielding RA, Gill TM, Groessl EJ, et al. Effect of structured physical activity on prevention of major mobility disability in older adults the LIFE study randomized clinical trial. Jama-J Am Med Assoc. 2014;311(23):2387-96.

16. Hock M, Takács K, Figler M. Sarcopenia and exercise as determinants of well-being in elderly - a pilot study. J Proactive Med. 2015;3(1):5-10.

17. Bangsbo J, Blackwell J, Boraxbekk C-J, Caserotti P, Dela F, Evans AB, Jespersen AP, Gliemann L, Kramer AF, Lundbye-Jensen J. Copenhagen consensus statement 2019: physical activity and ageing. Br J Sports Med. 2019;53(14):856-8 
18. Physical Activity Basics, Retrieved 30/06, 2019, from [https://www.cdc.gov/ physicalactivity/basics/].

19. Albuquerque APA, Borges-Silva F, Borges EGD, Pereira AP, Dantas EHM. Physical activity: relationship to quality of life and memory in older people. Science Sports. 2017;32(5):259-65.

20. Body mass index - BMl (Retrieved 03 01, 2018, from) [http://www.euro.who. int/en/health-topics/disease-prevention/nutrition/a-healthy-lifestyle/bodymass-index-bmi].

21. WHO. WHO STEPS surveillance manual: the WHO STEPwise approach to chronic disease risk factor surveillance. Geneva: World Health Organization; 2008.

22. WHO: Waist circumference and waist-hip ratio: report of a WHO expert consultation, Geneva, 8-11 December 2008. 2011.

23. Cleland CL, Hunter RF, Kee F, Cupples ME, Sallis JF, Tully MA. Validity of the global physical activity questionnaire (GPAQ) in assessing levels and change in moderate-vigorous physical activity and sedentary behaviour. BMC Public Health. 2014;14

24. Bull FC, Maslin TS, Armstrong T. Global physical activity questionnaire (GPAQ): nine country reliability and validity study. J Phys Act Health. 2009; 6(6):790-804.

25. Armstrong T, Bull F. Development of the World Health Organization global physical activity questionnaire (GPAQ). J Public Health. 2006;14(2):66-70.

26. Mengesha MM, Roba HS, Ayele BH, Beyene AS. Level of physical activity among urban adults and the socio-demographic correlates: a populationbased cross-sectional study using the global physical activity questionnaire. BMC Public Health. 2019;19:1.

27. Ellis G, Hunter RF, Hino AAF, Cleland CL, Ferguson S, Murtagh B, Anez CRR, Melo S, Tully M, Kee F, et al. Study protocol: healthy urban living and ageing in place (HULAP): an international, mixed methods study examining the associations between physical activity, built and social environments for older adults the UK and Brazil. BMC Public Health. 2018;18.

28. Ács P, Betlehem J, Oláh A, Bergier B, Morvay-Sey K, Makai A, Prémusz V. Cross-cultural adaptation and validation of the Global Physical Activity Questionnaire among healthy Hungarian adults. BMC Public Health. 2020. https://doi.org/10.1186/s12889-020-08477-z.

29. Global Physical Activity Questionnaire (GPAQ) Analysis Guide V2 [https:// www.who.int/ncds/surveillance/steps/GPAQ\%20Instrument\%20and\%2 OAnalysis\%20Guide\%20v2.pdf].

30. Skevington SM, Lotfy M, O'Connell KA. The World Health Organization's WHOQOL-BREF quality of life assessment: psychometric properties and results of the international field trial - a report from the WHOQOL group. Qual Life Res. 2004;13(2):299-310.

31. Paulik E, Belec B, Molnár R, Müller A, Belicza É, Kullmann L, Nagymajtényi L. Applicability of the brief version of the World Health Organization's quality of life questionnaire in Hungary. Orv Hetil. 2007;148(4):155-60.

32. Power M, Kuyken W, Orley J, Herrman H, Schofield H, Murphy B, Metelko Z, Szabo S, Pibernik-Okanovic M, Quemada N, et al. The World Health Organization quality of life assessment (WHOQOL): development and general psychometric properties. Soc Sci Med. 1998;46(12):1569-85.

33. WMA. World Medical Association Declaration of Helsinki. Ethical principles for medical research involving human subjects. Bull World Health Org. 2001; 79(4):373.

34. Baxter S, Johnson M, Payne N, Buckley-Woods H, Blank L, Hock E, Daley A, Taylor A, Pavey T, Mountain G, et al. Promoting and maintaining physical activity in the transition to retirement: a systematic review of interventions for adults around retirement age. Int J Behav Nutr Phys Act. 2016;13:12.

35. Barnett I, van Sluijs EMF, Ogilvie D. Physical activity and transitioning to retirement a systematic review. Am J Prev Med. 2012;43(3):329-36.

36. Kampfen F, Maurer J. Time to burn (calories)? The impact of retirement on physical activity among mature Americans. J Health Econ. 2016;45: 91-102.

37. Mitas J, Ding D, Fromel K, Kerr J. Physical activity, sedentary behavior, and body mass index in the Czech Republic: a nationally representative survey. J Phys Act Health. 2014;11(5):903-7.

38. HHS USDoHaHS: The Physical Activity Guidelines for Americans, 2nd edition, Date Accessed 08/06, 2019, from In.: Physical Activity Guidelines Advisory Committee; 2018.

39. Myers J, McAuley P, Lavie CJ, Despres JP, Arena R, Kokkinos P. Physical activity and cardiorespiratory fitness as major markers of cardiovascular risk: their independent and interwoven importance to health status. Prog Cardiovasc Dis. 2015;57(4):306-14.

40. Asp M, Simonsson B, Larm P, Molarius A. Physical mobility, physical activity, and obesity among elderly: findings from a large population-based Swedish survey. Public Health. 2017;147:84-91.

41. Freire RC, Fernandes TG, Borges GF, Guerra RO, de Abreu DCC. Factors associated with low levels of physical activity among elderly residents in a small urban area in the interior of the Brazilian Amazon. Arch Gerontol Geriatr. 2018;75:37-43.

42. Tribess S, Virtuoso JS, de Oliveira RJ. Physical activity as a predictor of absence of frailty in the elderly. Revista da Associação Médica Brasileira. 2012;58(3):341-7.

43. Brondeel R, Wasfi R, Perchoux C, Chaix B, Gerber P, Gauvin L, Richard L, Gaudreau P, Thierry B, Chevrier M, et al. Is older adults' physical activity during transport compensated during other activities? Comparing 4 study cohorts using GPS and accelerometer data. J Transp Health. 2019;12:229-36.

44. Oláh A, Sándor J, Boncz I, Betlehem J, Sebestyén A, Kisbenedekné Gulyás K, Dózsa C. Micro-regional disparities in home-based care in the South Transdanubian region [A kistérségi egyenlőtlenségek az otthoni szakápolás vonatkozásában a dél-dunántúli térségben]. Nővér. 2004;17(5):17.

45. Schorr AV, Khalaila R. Aging in place and quality of life among the elderly in Europe: a moderated mediation model. Arch Gerontol Geriatr. 2018;77:196-204.

46. Hock M, Kránicz L, Csiziné Ratár M, Bódis J, Deblasio A, Soós S. Sarcopenia in the elderly [ldőskori szarkopénia]. Fizioterápia. 2014;23(1):3-7.

47. Tahin T, Jeges $S$, Lampek K. Iskolai végzettség és egészségi állapot. Demográfia. 2000;43(1):70-93.

48. Cusatis R, Garbarski D. Different domains of physical activity: the role of leisure, housework/care work, and paid work in socioeconomic differences in reported physical activity. SSM-Population Health. 2019;7.

49. Pimenta FBC, Bertrand E, Mograbi DC, Shinohara H, Landeira-Fernandez J. The relationship between obesity and quality of life in Brazilian adults. Front Psychol. 2015;6.

50. Schrack JA, Zipunnikov V, Goldsmith J, Bai JW, Simonsick EM, Crainiceanu C, Ferrucci L. Assessing the "physical cliff": detailed quantification of agerelated differences in daily patterns of physical activity. J Gerontol Series A Biol Sci Med Sci. 2014:69(8):973-9.

51. Steeves JA, Shiroma EJ, Conger SA, Van Domelen D, Harris TB. Physical activity patterns and multimorbidity burden of older adults with different levels of functional status: NHANES 2003-2006. Disabil Health J. 2019:12(3):495-502.

52. Healthy and Positive Ageing Initiative. Positive aging. National Indicators report, Date Accessed 30/06, 2019, from. Dublin: Department of Health; 2018.

53. Pelclova J, Gaba A, Tlucakova L, Pospiech D. Association between physical activity (PA) guidelines and body composition variables in middle-aged and older women. Arch Gerontol Geriatr. 2012:55(2):E14-20.

54. Hamrik Z, Sigmundova D, Kalman M, Pavelka J, Sigmund E. Physical activity and sedentary behaviour in Czech adults: results from the GPAQ study. Eur J Sport Sci. 2014;14(2):193-8.

55. Watson KB: Physical inactivity among adults aged 50 years and older-United States. Morb Mortal Wkly Rep. 2014;2016:65.

56. Pelclova J, Fromel K, Repka E, Blaha L, Suchomel A, Fojtik I, Feltlova D, Valach P, Horak S, Nykodym J. Is pedometer-determined day-of-the-week variability of step counts related to age and BMI in Czech men and women aged 50 to 70 years? Acta Gymnica. 2016;46(1):21-9.

57. Gobbens RJJ, van Assen M. Associations between multidimensional frailty and quality of life among Dutch older people. Arch Gerontol Geriatr. 2017; 73:69-76.

58. Puciato D, Borysiuk Z, Rozpara M. Quality of life and physical activity in an older working-age population. Clin Interv Aging. 2017;12:1627-34.

59. Ramirez-Campillo R, Diaz D, Martinez-Salazar C, Valdes-Badilla P, Delgado-Floody P, Mendez-Rebolledo G, Canas-Jamet R, Cristi-Montero C, Garcia-Hermoso A, Celis-Morales C, et al. Effects of different doses of high-speed resistance training on physical performance and quality of life in older women: a randomized controlled trial. Clin Interv Aging. 2016;11:1797-804.

60. Krzepota J, Biernat E, Florkiewicz B. The relationship between levels of physical activity and quality of life among students of the university of the third age. Cent Eur J Public Health. 2015;23(4):335-9.

61. Omorou YA, Erpelding ML, Escalon H, Vuillemin A. Contribution of taking part in sport to the association between physical activity and quality of life. Qual Life Res. 2013;22(8):2021-9. 
62. Makai A, Prémusz V, Füge K, Figler M, Lampek K. Social participation and health among ageing people in east-Central Europe. Pract Theory Syst Education. 2015;10(2):177-85.

63. Olah A, Betlehem J, Kriszbacher I, Boncz I, Bodis J, In response to, Defloor T, Van Hecke A, Verhaeghe S, Gobert M, Darras E, Grypdonck M. The clinical nursing competences and their complexity in Belgian general hospitals. Journal of advanced nursing 56(6), 669-678. J Adv Nurs. 2006;58(3):301-2.

64. Acs P, Stocker M, Fuge K, Paar D, Olah A, Kovacs A. Economic and public health benefits: the result of increased regular physical activity. Eur J Integ Med. 2016;8:8-12.

\section{Publisher's Note}

Springer Nature remains neutral with regard to jurisdictional claims in published maps and institutional affiliations.

Ready to submit your research? Choose BMC and benefit from:

- fast, convenient online submission

- thorough peer review by experienced researchers in your field

- rapid publication on acceptance

- support for research data, including large and complex data types

- gold Open Access which fosters wider collaboration and increased citations

- maximum visibility for your research: over $100 \mathrm{M}$ website views per year

At BMC, research is always in progress.

Learn more biomedcentral.com/submissions 